\title{
The Russian-Belarusian bilingualism in the Republic of Belarus today and the problems of pre-school education
}

\section{Introduction}

The Republic of Belarus is at the moment the only mainly Slavonic state that recognizes official bilingualism with the Belarusian and Russian languages. Recent research in social sciences has characterized Belarus as a "borderland", and linguistic research also adopts this perspective. The linguistic situation in Belarus can be described as bilingualism between two extremely closely related Slavonic languages.

Belarusian and Russian have similar grammatical structure with few significant differences between them (even if different kinds of orthographies consider the same grammatical features in different ways). The most distinctive features are pronunciation of some historical phonemes, a different principle of orthography and unique Belarusian vocabulary. There are also some different constructions such as смяящиа 3 каго, дзякаваць каму, чакаџь па нядзелях and stylistic discrepancies.

\section{Brief historical review and current situation}

One can consider the spread of the Polish culture and language among the nobility living on the Belarusian territories in the eighteenth century and through it among the local merchants and other middle-class people as one of the main preconditions for the future Russian-Belarusian bilingualism, because it was the reason why Belarusian finally lost its prestige and turned into a language of rural population.

In the late eighteenth century, Belarusian territories became part of the Russian Empire. The written Belarusian was banned from official use: Polish and Russian academics did not even recognize the Belarusian language as a separate 
language. This moment can be considered to be the beginning of the RussianBelarusian bilingualism. There were attempts to establish Russian as the language of the local nobility on the annexed territories. The period of a relatively tolerant language policy was followed by decades of aggressive Russification.

In the nineteenth century, the sense of distinctive Belarusian identity strengthened among Belarusian scientists brought up in the traditions of Polish and Russian cultures. After centuries of decline, there was a need for the Belarusian literary language to be revitalized. Old traditions were forgotten, and new practices were just beginning to take shape. The second half of the nineteenth century marked the beginning of the new Belarusian national literary and written language.

All the languages in the Russian empire were declared legal in 1905, which also meant freedom for the Belarusian press. This change boosted Belarusian publishing activity for several years and the publications written in Belarusian competed with those in Polish and Russian. In 1918 the first school grammar of the Belarusian language was published. In the 1920s Belarusian acquired the status of one of the four state languages as a result of the implementation of policies of "Belarusization". For the first time, school books and numerous dictionaries were written in Belarusian. Belarusian was introduced as the language of bookkeeping and science.

In the 1930s the "Belarusization" process began to slow down. Since that time and until today the Russian language has been openly preferred. In 1933 a great orthographical reform was carried out. Its purpose was to bring Belarusian closer to Russian and minimize contradictions between the two languages. Since 1959 students were allowed not to study Belarusian at schools, which also led to a decrease in the use of the Belarusian language.

The Republic of Belarus declared independence in 1991. The Belarusian language was given the status of the only official state language according to the 
model of the other ex-Soviet states. During the first years of independence, several new dictionaries were published and the Belarusian language was prepared to be a sovereign national language to replace Russian as the dominant language of the society.

However, the methods used for the revival of national culture were forceful and compulsory. The language of education was no longer Russian but Belarusian, and this change puzzled many and was even met with opposition by some others. The initial enthusiasm about the national revival in the academic sphere languished in a couple of years because of the disruptions of well-established conventions of verbal culture in the newborn nation. The second national revival of the Belarusian failed and in 1994 Russian-speaking Alexander Lukashenka, who gained great popularity among the people, was elected the president of the Republic of Belarus.

As a result of the referendum conducted in 1995, two languages - Belarusian and Russian - were given the status of state languages. The adoption of Russian as an official language provoked antipathy among supporters of the Belarusian language. Since 1998,representatives of Belarusian bureaucracy have had a right to choose their language (Zaprudnik,2003, p. 117).

One of the peculiarities of the linguistic situation in Belarus is the emergence of a Belarusian - Russian hybrid nicknamed trasyanka (literally "a mixture of hay and straw", see Hentschel, Taranenko, \& Zaprudski, 2014). Trasyankais not a conscious verbal style but a natural way of speaking among millions of Belarusians, though it has been viewed as an unwanted form of language and a sign of bad taste.

Speaking about the ethnolinguistic structure of Belarus, it is worth noting that the state is predominantly mono-ethnic, with ethnic Belarusians as the overwhelming majority of population. Ethnic Russians comprise approximately 
one-tenth of the entire population, but it does not correspond with the language preferences. Here are the results of the two last censuses in Belarus:

\begin{tabular}{|lccc|}
\hline Census & 1999 (Belstat) & 2009 (Belstat) & Tendency \\
\hline Population total & 10.0452 millions & 9.5038 millions & $\mathrm{V}$ \\
Eth. Belarusians & $81.2 \%$ & $83.7 \%$ & $\wedge$ \\
Eth. Russians & $11.4 \%$ & $8.3 \%$ & $\mathrm{~V}$ \\
Eth. Polish & $3.9 \%$ & $3.1 \%$ & $\mathrm{~V}$ \\
Eth. Ukrainian & $2.4 \%$ & $1.7 \%$ & $\mathrm{~V}$ \\
Belarusian as native & $73.7 \%$ & $53.2 \%$ & $\mathrm{~V}$ \\
Belarusian as domestic & $36.7 \%$ & $23.4 \%$ & $\mathrm{~V}$ \\
Russian as native & $24.1 \%$ & \lrcorner $41.5 \%$ & $\wedge$ \\
Russian as domestic & $62.8 \%$ & $70.2 \%$ & $\wedge$ \\
\hline
\end{tabular}

The most significant change is in the status of the Belarusian language. The number of people calling Belarusian their native language has dropped, while the number of people calling Russian their native language has increased. When the results of the census were published in 2010, the newspaper Nasha Niva summarized them as follows: "More Belarusians in Belarus but they are getting russified"(Misyukevich,2010).

Most studies agree that Belarusian is not dying out, but its prospects of becoming the leading language of the country are relatively bleak. This would require a change from an everyday tool of communication to a clear national symbol. The Belarusian language still carries some of the negative associations as a language of "simple countrymen" and it is also colored by the political opinions about the Belarusian language as a product of bourgeois nationalism (Gapova, p. 
47); so its use in the public sphere is considered to be a political statement. In this sense, the image of Russian is more neutral (Norman, 2009, p. 11).

Yet, there are signs of emerging prestige of the Belarusian language among the young. One of the main forces behind the growing value of the language is the interest of the Belarusian youth in the history of their home country (see Woolhiser, 2014on the linguistic construction of identity in Belarus). The most popular genre of the Belarusian literature at the moment is historical fiction

looking into the history of Belarus. Evening parties are organized with a purpose of using the Belarusian language in specially prepared programs and in informal communication among participants. There exist quite a number of music groups and individual singers performing songs (mainly rock and folk) in Belarusian. There are also a significant number of newspapers and magazines, radio channels and internet projects that use the Belarusian language. Catholic Church also uses Belarusian in most spheres of its practice.

Most parents choose the Russian language as the primary language of their children's education at school. But for that minority who want their children to study in Belarusian, it is difficult to find continuity in education, especially at the secondary and high-school level (Ulasiuk, 2011, p. 9).

\section{Language learning in pre-school education as the keys to the future}

The Belarusian language is considered native when the criterion of identification is applied. Spontaneous learning of Belarusian leads to confusion between Russian and Belarusian in the children's speech. Preschoolers' speech development is characterized by receptive and to a certain degree reproductive bilingualism.

Psychologically, the correct way of teaching preschoolers Belarusian as a second and as a native language is a combination of two approaches. The first relies on unconscious assimilation of Belarusian in everyday communication by 
gradual immersion in the appropriate communicative environment; the second requires structured courses.

The content of communication and its forms can be both spontaneous and organized around phenomena of everyday life. In the first case, the language material presented to children is not systematically ordered. In the second case, children's activities (e.g. games) are organized in a way that makes covert acquisition of certain linguistic forms possible. Language training is carried out as a single process of communication and learning.

The amount of lexical, grammatical, phonetic material, as well as the sequence of its presentation is pre-determined and teaching techniques are carefully selected. Educational work compensates for the lack of everyday motivation to communicate in the Belarusian language. Language mastery in the situations of language learning (communicative games, talks, discussions etc.) is the same as in the spontaneous speech activity. This is also language immersion in a communicative environment although it is strictly organized. Linguistic information is presented to children in a concentrated form, which facilitates the processing of lexical, grammatical and phonetic material.

Teaching Belarusian as a second native language is constructed in accordance with the universal principles of mastering native and second languages. The leading principle of teaching is not only presentation of speech samples but also linguistic synthesis, the generalized ways of constructing statements in the Belarusian language. The gradual acquisition of elementary properties of the Belarusian language should begin at the age of $2-3$, when imitation dominates. It is important to insert Belarusian in different types of children's activities to promote receptive and reproductive bilingualism.

Teaching how to create independent statements in Belarusian begins at the early preschool age of 3-4. Teaching a child basic understanding of methods used 
to construct expressions in the Belarusian language must be implemented at the time of the most acute" language instinct". There is an opportunity to combine the features of simultaneous early learning of two languages in a situation of "one person in a situation of communication-one language" and the consecutive learning of two languages based on the meta-linguistic ability of children (Starzhynskaya, 2000).

A bilingual person in the situation of a closely related bilingualism is not in a position, especially at the initial stage, to completely "disconnect" from the first language. Therefore, teaching children the Belarusian language is based on the principle of integrating the first (Russian) language, aiming at the practical mastery of the second (Belarusian) language. This allows educators to control the process of comparing languages, facilitates fair comparison and helps avoid errors. Comparison allows a child to distinguish between the peculiarities of the Belarusian and Russian languages.

During the senior preschool age, a "faux research" of certain phenomena of the Belarusian language and comparing them with the Russian is introduced against the background of the formation of children's orientation in the language; with that the material in the Russian language should be superseded by that in the Belarusian language. An important role in children's language learning is the development of a differentiated mindset enabling them to make appropriate decisions whether to use Belarusian or Russian in a variety of communicative situations.

Methods of teaching preschool children different verbal skills combine techniques applied in native and second language teaching. With the help of the former, the linguistic phenomena happening in both, the Belarusian and Russian languages are introduced. This is particularly important for teaching Belarusian vocabulary and pronunciation skills. The bigger the difference between Belarusian 
and Russian thematic vocabularies, phonetics, and grammar, the bigger the need to teach the second language by applying the communicative approach. The receptive and reproductive nature of the closely related bilingualism allows for a wide use of entertaining language material in the Belarusian language (poems, riddles, songs etc.) in the teaching process. These texts provide examples of ambiguous words, synonyms and antonyms, the use of prefixes in word formation, peculiarities of pronunciation etc. Many teachers introduce elements of Belarusian folk games and discuss the content of teaching materials exclusively in Belarusian.

The methodology of teaching the Belarusian language is linked with the development of the national viewpoint among children. Therefore, the educational process is based on a linguo-cultural approach. Due to the proximity of the two linguistic systems, the Russian speaker understands Belarusian relatively easily. Literary works in Belarusian create psychological conditions for discussions of the content of the studied material in the national language. Thus the aim of symmetrical teaching of the Belarusian and Russian verbal heritage is to mobilize the pupils' awareness of the separation between the two extremely close languages by encouraging the children to discover unique characteristics of each.

As for secondary education, the purpose of the current school system of Belarus is to educate children as completely balanced Belarusian-Russian bilinguals (Titarenko, 2011). But the Belarusian language for most children is the second language viewed as the carrier of national and cultural identity. That makes teaching of Belarusian as a native language a complicated problem (Starzhynskaya, 2008, pp. 22-23).

Regarding the language situation in the educational field of Belarus, it is possible to say that the position of the titular language is somewhat similar to the position of minority languages in some countries. Since education in middle-high and high schools and on the tertiary level are provided primarily in Russian. Itis 
predictable that the Russian-language dominance will prevail in the entire society also in the future. According to Boris Norman, it is evident that at the moment the Belarusian is not going to replace Russian as the leading language of the society (Norman, 2009, p. 13).

\section{Conclusion}

The centuries of the Russian-Belarusian co-existence as one state and the conditions of "Russification" did not give the Belarusian language a chance to become firmly established in education, culture and science. At the same time, this led to a common information space, and modern communication technologies perpetuate and deepen the information dependence of Belarus on Russia. The Belarusian language is formally a state language, but its use as a means of communication is limited. It needs support in the form of "affirmative action".

There is a discrepancy between the first language and the language of national identity. So for those who regard the national language to be their mother tongue, Belarusian is an ethnic symbol. Belarus is an example of a country where we can observe a struggle for everyday use of the titular language rather than for equal opportunities for a minority language.

One of the important results of the bilingual history in Belarus is the emergence of the Belorusian-Russian hybrid trasyanka, widely used but treated as a non-prestigious variety. It might be on decline because of the new linguistic consciousness among the young. Further evolution of Belarusian-Russian bilingualism leading to a balanced form also poses a threat for trasyanka's vitality. The aim of the school system is to support this kind of development.

Education in Belarus is provided primarily in Russian. For those who want to teach their children in Belarusian, it can be a problem to find such a school. Nevertheless, in pre-school education, there area number of ways of teaching 
pupils Belarusian as a second and as a native language in the situation of closely related bilingualism, regarding the ways of avoiding or overcoming the interference-the methods discussed in this article.

\section{References}

Hentschel, G., Taranenko, O., \& Zaprudski, S. (2014) (Hrsg.). Trasjanka und Suržyk-gemischte weissrussisch-russische und ukrainisch-russische Rede. Peter Lang.

Misyukevich, Yu. (2010, September 8). Belarusaw stala bol'sh, ale yani rusifikuyutstsa [More Belarusians in Belarus but they are getting russified]. Nasha Niva. Retrieved fromhttp://nn.by/?c=ar\&i=43063

National Statistical Committee of the Republic of Belarus. Retrieved fromhttp://belstat.gov.by AQ5

Norman, B. (2009). Valkovenäjän kielen nykytila [Current Status of the Belarusian Language] (A. Lammi, Trans.). Idäntutkimus, 2/2009,3-13.

Starzhynskaya, N. S. (2000). Teoryya i metodyka razvitstsya belaruskaha mawlennya dashkol'nikaw [Theory and methodology for the development of the Belarusian language among preschoolers]. Minsk.

Starzhynskaya, N. S. (2008). Metodyka razvitstsya rodnay movy [Methodology for the development of the mother tongue]. Minsk: Vysheyshaya shkola.

Titarenko, L. (2011). The lectures about Belarus at the Helsinki University in autumn 2011.

Ulasiuk, I. (2011). Language policies and law in education in post-Soviet Belarus (ECMI Working Paper \#50). European Centre for Minority Issues. Retrieved fromhttp://www.ecmi.de/uploads/tx_lfpubdb/ ECMI_WP_50_Final.pdf 
Woolhiser, C. (2014). The Russian language in Belarus: Language use, speaker identities and metalinguistic discourse. In L. Ryazanova-Clarke (Ed.), The Russian language outside the nation (pp. 81-116). Edinburgh: Edinburgh University Press. Zaprudnik, J. (2003). Belarus: In search of national identity between 1986 and 2000. In E. A. Korosteleva, C. Lawson, \& R. J. Marsh (Eds.),Contemporary Belarus. Between democracy and dictatorship. London: Curzon. 